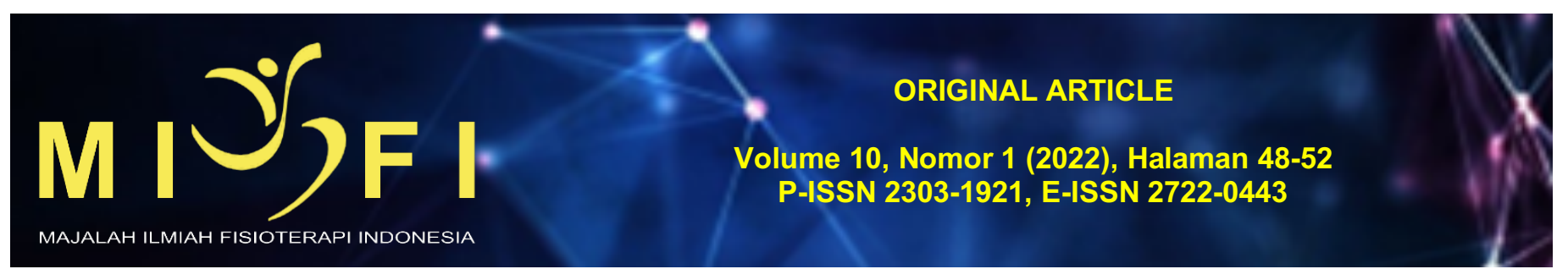

\title{
HUBUNGAN LINGKAR PINGGANG TERHADAP TEKANAN DARAH PADA PEREMPUAN DEWASA AKHIR DI DESA BATUAN SUKAWATI GIANYAR
}

\author{
Ni Luh Ade Utari'1, Putu Ayu Sita Saraswati², I Made Niko Winaya ${ }^{3}$, Ni Komang Ayu Juni Antari ${ }^{4}$ \\ ${ }^{1}$ Program Studi Sarjana Fisioterapi dan Profesi Fisioterapi, Fakultas Kedokteran Universitas Udayana, Denpasar, Bali \\ ${ }^{2,3,4}$ Departemen Fisioterapi, Fakultas Kedokteran Universitas Udayana, Denpasar, Bali \\ *Koresponden: uut5546@gmail.com
}

Diajukan: 21 Juni 2021 | Diterima: 28 Juni 2021 | Diterbitkan: 25 Januari 2022 DOI: https://doi.org/10.24843/MIFl.2022.v10.i01.p10

\begin{abstract}
ABSTRAK
Pendahuluan: Usia perempuan dibagi menjadi beberapa kelompok usia. Usia 36-45 tahun dikategorikan dalam kategori perempuan dewasa akhir. Masalah kesehatan seperti kelebihan berat badan meningkat $40 \%$ pada masa perempuan dewasa. Kelebihan berat badan berkorelasi dengan lingkar pinggang yang lebih lebar. Seseorang yang memiliki lingkar pinggang yang lebih lebar maka dapat meningkatkan risiko penyakit yang timbul akibat obesitas, seperti hipertensi atau penyakit kardiovaskular lainnya. Hipertensi merupakan penyebab utama kematian dini di seluruh dunia termasuk 33\% di Indonesia. Tujuan penelitian ini adalah untuk mengetahui hubungan lingkar pinggang terhadap tekanan darah pada perempuan dewasa akhir di Desa Batuan, Sukawati, Gianyar.

Metode: Penelitian ini merupakan jenis penelitian observasional analitik dengan desain cross-sectional yang menggunakan teknik purposive sampling. Penelitian ini dilakukan pada bulan Februari-Maret 2021 dengan jumlah subjek sebanyak 68 orang. Variabel bebas dalam penelitian ini yaitu lingkar pinggang yang diukur menggunakan tape measure. Variabel terikat dalam penelitian ini adalah tekanan darah yang diukur menggunakan sphygmomanometer dan stetoskop.

Hasil: Uji analisis bivariat untuk mengetahui hubungan antara dua variabel ini menggunakan chi-square test. Hasil chi-square test menunjukkan bahwa nilai $p=0,126(p>0,05)$.

Simpulan: Tidak ada hubungan yang signifikan antara lingkar pinggang terhadap tekanan darah pada perempuan dewasa akhir di Desa Batuan, Sukawati, Gianyar.
\end{abstract}

Kata Kunci: perempuan dewasa, lingkar pinggang, tekanan darah

\section{PENDAHULUAN}

Masa perempuan dewasa menurut Departemen Kesehatan Republik Indonesia tahun 2009 terdiri atas masa dewasa awal dan masa dewasa akhir. Masa dewasa awal yaitu antara rentangan usia 26-35 tahun sedangkan masa dewasa akhir berada pada rentangan usia 36-45 tahun. ${ }^{1}$ WHO menjelaskan bahwa overweight meningkat pada orang dewasa pada tahun 2016 menjadi 39\% pada laki-laki dan 40\% pada perempuan. Kelebihan berat badan terbukti berkorelasi dengan lingkar pinggang yang lebih lebar. Lingkar pinggang merupakan pengukuran yang mudah untuk dilakukan karena hanya mencakup otot skeletal, tulang, lemak dan tanpa memperhatikan hip. Lingkar pinggang sering digunakan karena lingkar pinggang memiliki korelasi dengan massa lemak tubuh (subkutan dan intra-abdominal). ${ }^{2}$

Seseorang yang memiliki lingkar pinggang yang lebih lebar maka dapat meningkatkan risiko penyakit yang timbul akibat obesitas, yaitu diabetes maupun penyakit kardiovaskular lainnya seperti hipertensi. Hipertensi sering disebut "silent killer" yakni 1,13 miliar orang diseluruh dunia menderita hipertensi dan 2/3 tinggal di negara berpenghasilan rendah dan menengah. Peningkatan kejadian hipertensi dari 594 juta menjadi 1,13 miliar pada tahun 2015 disebabkan oleh meningkatnya faktor risiko hipertensi pada populasi tersebut terutama pada negara-negara berpenghasilan rendah dan menengah. ${ }^{3}$

World Health Organization (WHO) menyatakan bahwa hipertensi secara signifikan meningkatkan risiko penyakit jantung, otak, ginjal, dan penyakit lainnya. Peningkatan tekanan darah juga dapat memicu timbulnya faktor risiko disability adjusted life years (DALYs) secara global. Hal yang sangat membahayakan adalah komplikasi hipertensi seperti angina, serangan jantung karena tersumbatnya suplai darah menuju jantung dan sel-sel otot jantung tidak berfungsi karena kekurangan oksigen, gagal jantung yang terjadi karena jantung tidak dapat memompa darah dan oksigen dengan cukup menuju organ tubuh vital lainnya, serta detak jantung tidak teratur yang menyebabkan kematian mendadak. Selain itu, hipertensi juga dapat menyebabkan stroke karena menyumbat arteri yang menyuplai darah dan oksigen menuju otak serta dapat menyebabkan gagal ginjal. Berdasarkan komplikasi yang ditimbulkan, sangat perlu dilakukan pemahaman mengenai informasi faktor risiko yang telah teruji korelasinya terhadap kejadian tekanan darah tinggi. $^{3}$

Salah satu faktor risiko tersebut yaitu berat badan berlebih yang sering disebut overweight bahkan obesitas yang dapat dilakukan pengukuran lingkar pinggang. Studi epidemiologi juga menyebutkan rendahnya indeks massa tubuh namun lebarnya lingkar pinggang menunjukkan terjadinya risiko tekanan darah tinggi. ${ }^{4} \mathrm{Hal}$ ini sejalan dengan 
penelitian sebelumnya yang menyatakan fakta terkait lingkar pinggang sebagai kontribusi utama terhadap nilai tekanan darah sistolik dan tekanan darah diastolik di Indonesia. Ukuran lingkar pinggang yang abnormal menyebabkan terjadinya penurunan kadar adiponektin (adipositokin yang dihasilkan oleh jaringan lemak) sebagai antiaterogenik (menghambat oksidasi low density lipoprotein) sehingga turunnya kadar protein spesifik ini menyebabkan tekanan darah mengalami peningkatan. ${ }^{5}$ Tujuan penelitian ini adalah untuk mengetahui hubungan lingkar pinggang terhadap tekanan darah pada perempuan dewasa akhir Desa Batuan, Sukawati, Gianyar.

\section{METODE}

Desain penelitian yang digunakan yaitu observasional analitik menggunakan studi cross-sectional. Penelitian dilaksanakan pada bulan Februari - Maret 2021 pada perempuan dewasa akhir Desa Batuan, Sukawati, Gianyar. Subjek penelitian berjumlah 68 orang menggunakan teknik purposive sampling. Pemilihan subjek penelitian menggunakan kriteria inklusi yaitu perempuan dewasa akhir berusia 36-45 tahun, bersedia secara sukarela menjadi subjek penelitian dari awal sampai akhir penelitian dengan menandatangani informed consent, dan memiliki aktivitas fisik sedang yang diukur menggunakan kuesioner global physical activity questionnaire (GPAQ). Sementara kriteria eksklusi pada penelitian ini, meliputi: adanya riwayat keluarga yang mengalami hipertensi dan penyakit metabolik (diabetes mellitus, gout arthritis, dan hiperkolesterolemia), mengonsumsi golongan obat ACE inhibitor dan calcium channel blocker (CCB), riwayat merokok, mengonsumsi alkohol yang diketahui melalui form anamnesis.

Pada penelitian ini, variabel independen yakni lingkar pinggang diukur menggunakan tape measure. Penelitian terdahulu belum ada yang melaporkan mengenai nilai validitas dan reliabilitas tape measure dalam mengukur lingkar pinggang. Pengukuran lingkar pinggang dilakukan dengan cara: 1) Pengukur berdiri disamping partisipan, letakkan dan tandai inferior margin rib ke-duabelas dan iliac crest (diatas tulang pinggul) dengan pulpen, 2) Temukan midpoint, lalu tandai point tersebut dengan tape measure, 3) Aplikasikan tension tape pada midpoint dan meminta partisipan untuk melilitkan tape pada midpoint yang telah ditandai. Periksa apakah tape measure sudah mendatar dibagian belakang dan depan partisipan, 4) Meminta partisipan untuk berdiri dengan kedua kakinya, meletakkan lengan disamping tubuhnya dengan palmar menghadap kedalam, kemudian mengeluarkan napas dengan gentle, 5) Pengukur mengukur lingkar pinggang dan membaca hasil pengukuran (pengukuran hanya dilakukan satu kali). ${ }^{6}$ Lingkar pinggang $\leq 88$ centimeter menunjukkan nilai lingkar pinggang normal dan $>88$ centimeter menunjukkan angka lingkar pinggang abnormal dan merupakan risiko terjadinya penyakit kardiometabolik. ${ }^{7}$

Variabel dependen yaitu tekanan darah diukur menggunakan sphygmomanometer dan stetoskop. Validitas dan reliabilitas sphygmomanometer yaitu high agreement (kappa $=0,881, p<0,001) .{ }^{8}$ Pengukuran tekanan darah dilakukan melalui beberapa tahap meliputi: 1) Subjek dalam posisi duduk atau supine dengan posisi lengan terletak setinggi jantung. Pastikan pasien tidak memakai baju ketat yang dapat menekan pembuluh darah lengan, 2) Palpasi arteri brakialis bagian medial pada fossa antecubiti dan cari arteri yang pulsasinya paling kuat, 3) Pasang manset pada lengan pasien. Bagian yang berisi tanda atau gambar arteri tepat berada diatas arteri brakialis dan tepi bagian bawahnya \pm 2 $\mathrm{cm}$ dari fossa antecubiti. Pemasangan tidak boleh terlalu longgar atau ketat, 4) Estimasi tekanan darah sistolik dilakukan dengan melakukan palpasi arteri radialis pasien dengan dua atau tiga jari tengah, kemudian pompa kantung udara sambil jari pemeriksa meraba arteri radialis sampai nadi tidak teraba. Catat pada tekanan berapa nadi tersebut tidak teraba lagi (sebagai perkiraan tekanan darah sistolik). Kemudian kempeskan kantung udara sampai sempurna, 5) Ukur tekanan darah sistolik dan diastolic secara auskultasi dengan menggunakan stetoskop tepat diatas arteri brakialis. Pompa kantung udara sampai batas $20 \mathrm{mmHg}$ diatas perkiraan tekanan darah sistolik (tekanan darah saat nadi tidak teraba tadi). Kempeskan kantung udara secara perlahan-lahan (20 mmHg/denyut nadi), dan dengarkan suara nadi yang timbul (korotkoff 1-5). Jika masih ragu-ragu dapat dilakukan pengukuran tekanan darah seperti diatas, lalu ambil nilai rata-rata, 6) Lepas manset setelah menggunakan stetoskop cuci bagian corong stetoskop dan yang menempel di telinga dengan kapas alkohol. ${ }^{9}$ Kategori tekanan darah orang dewasa dikategorikan dalam tekanan darah rendah (90/60 mmHg atau lebih rendah), tekanan darah normal $(>90 / 60 \mathrm{mmHg}$ dan $<120 / 80 \mathrm{mmHg}$ ), tekanan darah pre-high (>120/80 dan $<140 / 90 \mathrm{mmHg})$, serta tekanan darah tinggi $(\geq 140 / 90 \mathrm{mmHg}) .^{10}$

Variabel kontrol yaitu usia, jenis kelamin dan aktivitas fisik. Penelitian ini diawali dengan menjelaskan tujuan, manfaat dan prosedur penelitian kemudian dilanjutkan dengan pengisian informed consent dan wawancara menggunakan kuesioner terkait aktivitas fisik, pengonsumsian obat anti hipertensi, riwayat penyakit metabolik, riwayat merokok, penggunaan alkohol, usia dan riwayat mengalami hipertensi. Setelah itu dilakukan pengukuran lingkar pinggang dan tekanan darah. Untuk mengetahui gambaran karakteristik sampel penelitian digunakan analisis univariat dan chi-square test sebagai analisis bivariat digunakan untuk mengetahui hubungan antara lingkar pinggang terhadap tekanan darah. Penelitian ini telah disetujui oleh Komisi Etik Penelitian (KEP) Fakultas Kedokteran Universitas Udayana/Rumah Sakit Umum Pusat Sanglah Denpasar dengan Nomor 1733/UN14.2.2.VII.14/LT/2020.

\section{HASIL}

Berikut merupakan hasil penelitian yang dilakukan pada 68 orang perempuan dewasa akhir di Desa Batuan, Sukawati, Gianyar yang berusia 36-45 tahun berdasarkan usia, lingkar pinggang dan tekanan darah.

Tabel 1. Karakteristik Sampel Penelitian

\begin{tabular}{ccc}
\hline Jenis Data & Frekuensi $(\mathrm{n})$ & Persentase (\%) \\
\hline Usia & & \\
36 & 15 & 22,1 \\
37 & 12 & 17,6 \\
38 & 2 & 2,9 \\
39 & 11 & 16,2 \\
\hline
\end{tabular}




\begin{tabular}{ccc}
\multicolumn{4}{c}{ Lanjutan Tabel 1. Karakteristik } & Sampel Penelitian \\
\hline Jenis Data & Frekuensi (n) & Persentase (\%) \\
\hline 40 & 6 & 8,8 \\
41 & 16 & 23,5 \\
42 & 1 & 1,5 \\
43 & 1 & 1,5 \\
45 & 4 & 5,9 \\
Lingkar Pinggang & & \\
Normal & 49 & 72,1 \\
Tidak normal & 19 & 27,9 \\
Tekanan Darah & & \\
Rendah & 0 & 0 \\
Normal & 65 & 95,6 \\
Pre-high & 3 & 4,4 \\
Tinggi & 0 & 0 \\
\hline
\end{tabular}

Berdasarkan Tabel 1. dapat dilihat bahwa dari 68 orang sampel penelitian, terdapat 15 orang $(22,1 \%)$ berusia 36 tahun, 12 orang $(17,6 \%)$ berusia 37 tahun, 2 orang $(2,9 \%)$ berusia 38 tahun, 11 orang $(16,2 \%)$ berusia 39 tahun, 6 orang $(8,8 \%)$ berusia 40 tahun, 16 orang $(23,5 \%)$ berusia 41 tahun, 1 orang $(1,5 \%)$ berusia 42 tahun, 1 orang $(1,5 \%)$ berusia 43 tahun, dan 4 orang $(5,9 \%)$ berusia 45 tahun. Berdasarkan data lingkar pinggang terdapat 49 orang $(72,1 \%)$ memiliki lingkar pinggang kategori normal yaitu sebesar $\leq 88 \mathrm{~cm}$ dan 19 orang $(27,9 \%)$ memiliki lingkar pinggang yang tidak normal yaitu sebesar $>88 \mathrm{~cm}$. Berdasarkan data tekanan darah terdapat 0 orang $(0 \%)$ memiliki tekanan darah rendah, 65 orang $(95,6 \%)$ memiliki tekanan darah normal, 3 orang $(4,4 \%)$ memiliki tekanan darah pre-high dan 0 orang $(0 \%)$ memiliki tekanan darah tinggi.

Tabel 2. Hubungan Lingkar Pinggang terhadap Tekanan Darah

\begin{tabular}{|c|c|c|c|c|c|c|c|c|c|c|c|}
\hline \multirow{3}{*}{ Lingkar Pinggang } & \multicolumn{8}{|c|}{ Tekanan Darah } & \multirow{2}{*}{\multicolumn{2}{|c|}{ Total }} & \multirow{3}{*}{$P$} \\
\hline & \multicolumn{2}{|c|}{ Rendah } & \multicolumn{2}{|c|}{ Normal } & \multicolumn{2}{|c|}{ Pre-High } & \multicolumn{2}{|c|}{ Tinggi } & & & \\
\hline & $\mathrm{n}$ & $\%$ & $\mathrm{~N}$ & $\%$ & $\mathrm{n}$ & $\%$ & $\mathrm{~N}$ & $\%$ & $\mathrm{n}$ & $\%$ & \\
\hline Normal & 0 & 0 & 48 & 70,6 & 1 & 1,5 & 0 & 0 & 49 & 72,1 & 0,126 \\
\hline Tidak normal & 0 & 0 & 17 & 25 & 2 & 2,9 & 0 & 0 & 19 & 27,9 & \\
\hline Jumlah & 0 & 0 & 65 & 0 & 3 & 0 & 0 & 0 & 68 & 100 & \\
\hline
\end{tabular}

Hasil uji analisis bivariat berupa chi-square pada Tabel 2. menunjukkan $p$-value atau nilai $p$ sebesar 0,126 . Nilai p-lebih besar dari 0,05 yang memiliki arti tidak terdapat hubungan yang signifikan antara lingkar pinggang terhadap tekanan darah pada perempuan dewasa akhir Desa Batuan, Sukawati, Gianyar.

\section{DISKUSI}

\section{Karakteristik Subjek Penelitian}

Subjek penelitian merupakan masyarakat perempuan dewasa akhir di Desa Batuan, Sukawati, Gianyar yang berjumlah 68 orang yang berusia 36-45 tahun dan telah memenuhi kriteria inklusi. Data yang digunakan oleh peneliti yaitu data primer melalui pengambilan data berupa pengukuran lingkar pinggang dan tekanan darah secara langsung pada subjek penelitian. Hasil penelitian mengenai karakteristik usia subjek penelitian dengan jumlah terbanyak pada usia 41 tahun berjumlah 16 orang $(23,5 \%)$, usia termuda yaitu 36 tahun berjumlah 15 orang $(22,1 \%)$, dan usia tertua yaitu 45 tahun berjumlah 4 orang $(5,9 \%)$.

Pada kriteria inklusi, subjek penelitian harus memiliki aktivitas fisik sedang. Hal ini didukung oleh penelitian Sihotang dan Elon 2020 bahwa adanya hubungan antara aktivitas fisik dengan tekanan darah diastolik. Aktivitas fisik sedang sampai tinggi dapat mempengaruhi turunnya tekanan darah karena dapat mengurangi kerja saraf simpatis, resistensi perifer menjadi berkurang, dapat menekan aktivitas renin sehingga terjadi vasodilatasi pembuluh darah kemudian tekanan darah menurun. Hasil penelitian yang serupa menyebutkan adanya korelasi yang bermakna antara aktivitas fisik dan tekanan darah yaitu $p<0,03$. Seseorang yang melakukan aktivitas fisik secara teratur menyebabkan peningkatan kebugaran kardiorespirasi dan tekanan darah yang stabil. ${ }^{11}$

Hasil penelitian mengenai distribusi frekuensi lingkar pinggang subjek penelitian menunjukkan bahwa terdapat 49 orang $(72,1 \%)$ memiliki lingkar pinggang kategori normal dan 19 orang $(27,9 \%)$ memiliki lingkar pinggang yang tidak normal. Penelitian yang dilakukan oleh Oviyanti 2010 pada wanita berusia $25-45$ tahun juga menunjukkan hasil yaitu 16 orang $(47,06 \%)$ memiliki lingkar pinggang normal dan tidak berisiko mengalami hipertensi. ${ }^{12}$ Penelitian lain tahun 2018 pada seseorang yang berusia $20-60$ tahun juga menyebutkan bahwa 26 orang $(51,0 \%)$ memiliki lingkar pinggang normal dan 25 orang (49\%) memiliki lingkar pinggang berlebih. ${ }^{13}$ Penelitian lain tahun 2017 yang dilakukan pada orang Indonesia berusia lebih dari 40 tahun juga mendapatkan hasil yang serupa yakni sebanyak 31,9\% perempuan memiliki lingkar pinggang normal. ${ }^{14}$ Hasil ini juga sesuai dengan penelitian lain yang menyatakan bahwa 30 orang $(65,2 \%)$ memiliki lingkar pinggang normal yaitu $\leq 88 \mathrm{~cm}$ dan 16 orang $(34,8 \%)$ memiliki lingkar pinggang berlebih yaitu $>88 \mathrm{~cm} .{ }^{15}$ Hasil penelitian mengenai distribusi frekuensi tekanan darah pada subjek penelitian tercantum bahwa dari 68 orang, 65 orang $(95,6 \%)$ memiliki tekanan darah normal, 3 orang $(4,4 \%)$ memiliki tekanan darah pre-high dan $0 \%$ atau tidak ada subjek penelitian yang memiliki tekanan darah rendah dan tekanan darah tinggi. Hasil ini sejalan dengan penelitian lain tahun 2020 yang dilakukan pada wanita dewasa berusia 20-49 tahun menyebutkan 33\% responden memiliki tekanan darah sistolik normal, 31\% tekanan darah meningkat, $7 \%$ hipertensi stage I, 27\% hipertensi stage II, dan 2\% hipertensi urgency. ${ }^{(16)}$ Penelitian lain tahun 2018 yang dilakukan pada seseorang yang berusia 19-64 tahun juga menyebutkan bahwa sebanyak 164 orang $(75,6 \%)$ tidak memiliki riwayat hipertensi atau memiliki tekanan darah normal. ${ }^{(17)}$ 


\section{Hubungan Lingkar Pinggang terhadap Tekanan Darah}

Hasil chi-square test tidak menunjukkan adanya hubungan yang signifikan antara variabel bebas (lingkar pinggang) dan variabel terikat (tekanan darah) yang ditunjukkan dengan nilai $\mathrm{p}>0,05(0,126)$ yang berarti $\mathrm{H}_{0}$ diterima dan $\mathrm{H}_{a}$ ditolak. Penelitian yang dilakukan oleh Arianti dan Husna juga menunjukkan bahwa $p=0,651$ yakni tidak terdapat hubungan yang signifikan antara lingkar pinggang dan tekanan darah masyarakat Aceh. ${ }^{18}$ Hasil penelitian ini mungkin disebabkan oleh kriteria inklusi subjek penelitian yaitu keberadaan sampel di wilayah pedesaan. Menurut Bustan, orang yang tinggal di wilayah pedesaan lebih sedikit ditemukan seseorang yang mengalami hipertensi dibandingkan orang yang hidup di wilayah perkotaan. ${ }^{19}$ Penelitian lain juga menyatakan tidak ada hubungan yang signifikan antara lingkar pinggang terhadap tekanan darah diastolik pada subjek perempuan yaitu $p=0,170$ ( $p>0,05)$, namun antara lingkar pinggang dengan tekanan darah sistolik ditunjukkan ada hubungan yang signifikan yaitu $p=0,01(p<0,05)$ dan memiliki korelasi sedang dengan nilai $r=0,540$. Menurut Oviyanti, tidak terjadi hubungan yang signifikan antara lingkar pinggang terhadap tekanan darah diastolik kemungkinan disebabkan oleh kesalahan pengambilan data pada subjek, yaitu penentuan bunyi korotkoff I dan $\mathrm{V}$ untuk menentukan tekanan darah sistolik dan diastolik, pembacaan ukuran lingkar pinggang yang kurang akurat, penempatan alat ukur lingkar pinggang terhadap posisi responden tidak tepat saat dilakukan pengukuran, faktor ekstrinsik seperti stress yang tidak mungkin sepenuhnya dikendalikan oleh peneliti, faktor lain yang tidak terkendali seperti hormonal, dan indeks massa tubuh (IMT).

Penelitian ini menggunakan subjek penelitian yang berusia 36-45 tahun yang dikategorikan sebagai perempuan dewasa akhir menurut literatur dari Departemen Kesehatan Republik Indonesia tahun 2009. Pada usia tersebut perempuan belum mengalami menopause sehingga hormon estrogen masih berperan dalam mengatur kadar high density lipoprotein (HDL) yang tinggi sehingga dapat mencegah aterosklerosis dan kerusakan pada pembuluh darah yang berkaitan terhadap nilai tekanan darah seseorang. ${ }^{20}$ Pemilihan rentang usia pada subjek penelitian akan menimbulkan hasil penelitian yang berbeda-beda. Seiring bertambahnya usia, tekanan darah juga cenderung meningkat karena terjadi perubahan pada arteri dan arteriol yang mengalami kekakuan, penurunan sensitivitas baroreseptor, respon terhadap rangsangan sistem saraf simpatis yang meningkat, dan perubahan metabolisme natrium dan ginjal serta renin-aldosteron. ${ }^{21}$

Hasil yang tidak signfikan pada penelitian ini juga dapat disebabkan oleh faktor genetik. Mutasi pada CYP1A2, gen yang terlibat dalam metabolisme beberapa xenobiotik termasuk hidrokarbon aromatik polisiklik dan metil xantin lainnya merupakan satu-satunya gen yang terkait dengan kejadian tekanan darah. Studi epidemiologi telah menunjukkan bahwa varian genetik tertentu, termasuk polimorfisme dalam gen yang mengkode angiotensinogen, $\alpha$ adducin, $\beta 3$ subunit protein $\mathrm{G}$ dan reseptor $\beta 2$-adrenergik dapat meningkatkan risiko hipertensi. ${ }^{22}$ Sedangkan pada penelitian ini menggunakan subjek yang tidak memiliki riwayat keluarga mengalami hipertensi yang diketahui melalui anamnesis.

Temuan lain yang juga berkaitan dengan hasil yang tidak signifikan pada penelitian ini dapat disebabkan oleh penentuan nilai titik potong lingkar pinggang pada perempuan dewasa akhir yang dapat mempengaruhi hasil penelitian yaitu karakteristik lingkar pinggang pada subjek. Pada penelitian ini menggunakan kategori lingkar pinggang normal $\leq 88$ centimeter dan kategori tidak normal jika lingkar pinggang menunjukkan angka $>88$ centimeter. Menurut Bantas \& Mulyono, penentuan nilai titik potong lingkar pinggang harus disesuaikan untuk setiap komunitas sebagai komponen penentu sindrom metabolik yang merupakan gangguan medis yang dapat meningkatkan penyakit kardiovaskular dan diabetes. Penelitian ini dilakukan agar sesuai dengan antropometri populasi orang Indonesia. Nilai titik potong optimal untuk mengidentifikasi subjek-subjek di Indonesia yaitu 83,5 centimeter untuk wanita Indonesia. ${ }^{23}$

Alasan lainnya dapat juga disebabkan karena "clever hans effect" yaitu responden penelitian seolah-olah mengubah respon agar sesuai dengan apa yang diinginkan oleh peneliti. Kemungkinan ketika dilakukan pengukuran, subjek tidak bernapas secara gentle sesuai dengan langkah keempat pengukuran lingkar pinggang yaitu meminta partisipan untuk berdiri dengan kedua kakinya, meletakkan lengan disamping tubuhnya dengan palmar menghadap ke dalam, kemudian mengeluarkan napas dengan gentle sehingga akan memberikan interpretasi yang berbeda pada hasil pengukuran. ${ }^{7}$ Hasil penelitian ini juga mungkin disebabkan oleh karakteristik lingkar pinggang responden cenderung normal. Jika lingkar pinggang berada dalam kategori normal maka tidak terjadi disfungsional jaringan adiposa dan kadar adiponektin tidak menurun sehingga tidak terjadi peningkatan leptin, inflamasi, kemudian peningkatan arterial stiffness dan disfungsi endotel sehingga hipertensi atau tekanan darah tinggi tidak terjadi. ${ }^{24}$

\section{SIMPULAN}

Berdasarkan hasil penelitian dapat disimpulkan bahwa tidak terdapat hubungan yang signifikan antara lingkar pinggang terhadap tekanan darah pada perempuan dewasa akhir di Desa Batuan, Sukawati, Gianyar.

Berdasarkan serangkaian proses penelitian yang sudah dilakukan, terdapat saran yang dapat diberikan oleh peneliti yaitu mempertimbangkan nilai titik potong angka lingkar pinggang yang digunakan pada subjek penelitian untuk menentukan kategori lingkar pinggang normal dan tidak normal. Meskipun hasil penelitian tidak menunjukkan adanya hubungan yang signifikan antara lingkar pinggang terhadap risiko tekanan darah tinggi, namun masyarakat sebaiknya tetap menjaga pola hidup sehat seperti melakukan aktivitas fisik selama 200-400 menit/minggu dengan intensitas sedang. Bagi peneliti lain yang ingin melakukan penelitian yang serupa maka variabel yang dapat mempengaruhi hasil penelitian dapat dikontrol seperti faktor stress, pola makan, mengonsumsi alkohol, dan riwayat merokok.

\section{DAFTAR PUSTAKA}

1. Sonang S, Purba AT, Pardede FOI. Pengelompokan Jumlah Penduduk Berdasarkan Kategori Usia Dengan Metode K-Means. J Tek Inf dan Komput. 2019;2(2):166.

2. Ross R, Neeland IJ, Yamashita S, Shai I, Seidell J, Magni P, et al. Waist circumference as a vital sign in clinical 
practice: a Consensus Statement from the IAS and ICCR Working Group on Visceral Obesity. Nat Rev Endocrinol [Internet]. 2020;16(3):177-89. Available from: http://dx.doi.org/10.1038/s41574-019-0310-7

3. WHO. No Title [Internet]. Available from: https://www.who.int/news-room/fact-sheets/detail/hypertension

4. Kuciene R, Dulskiene V. Associations between body mass index, waist circumference, waist-to-height ratio, and high blood pressure among adolescents: a cross-sectional study. Sci Rep [Internet]. 2019;9(1):1-11. Available from: http://dx.doi.org/10.1038/s41598-019-45956-9

5. Hafid MA. Hubungan Antara Lingkar Pinggang Terhadap Tekanan Darah dan Asam Urat di Dusun Sarite'ne Desa Bili-Bili. J Islam Nusing. 2018;3(1):54-61.

6. VVAA. Vital and Health Statistics Waist Circumference Measurement Methodology Study: National Health and Nutrition Examination Survey , 2016. 2016;(182).

7. Circumference W, Youssef A, Ahmed A. Comparing Measures of Obesity: [Internet]. 2nd ed. Nutrition in the Prevention and Treatment of Abdominal Obesity. Elsevier Inc.; 2019. 29-40 p. Available from: http://dx.doi.org/10.1016/B978-0-12-816093-0.00003-3

8. Article O, Shahbabu B, Dasgupta A, Sarkar K, Sahoo SK. Which is More Accurate in Measuring the Blood Pressure? A Digital or an Aneroid Sphygmomanometer. 2016;

9. Hall JE. Guyton and Hall Physiology Review (Guyton Physiology). 2nd ed. Saunders; 2011.

10. UK BP. What do the numbers mean? [Internet]. 2020 [cited 2021 Jun 25]. Available from: http://www.bloodpressureuk.org/your-blood-pressure/understanding-your-blood-pressure/what-do-the-numbersmean/

11. Hasanudin, Adriyani VM, Perwiraningtyas P. Hubungan Aktivitas Fisik Dengan Tekanan Darah Pada Masyarakat Penderita Hipertensi Di Wilayah Tlogosuryo Kelurahan Tlogomas Kecamatan Lowokwaru Kota Malang. J Nurs News. 2018;3(1):787-99.

12. Oviyanti PN. Hubungan antar lingkar pinggang dan rasio lingkar pinggang panggul dengan tekanan darah pada subjek usia dewasa. Skripsi Univ Sebel Maret. 2010;6-9.

13. Ermina L. Hubungan antara lingkar pinggang dan rasio lingkar pinggang panggul dengan tekanan darah pada anggota TNI Kodim 0735 Surakarta tahun 2017. Surakarta; 2018.

14. Kasyani K, Tinggi S, Kesehatan I, Susetyowati S, Mada UG, Kandarina I, et al. Lingkar pinggang dan hipertensi pada orang indonesia usia 40 tahun ke atas. 2017;(January 2019).

15. Rizki MU, Probosari E, Nissa C. Hubungan Lingkar Pinggang, Rasio Lingkar Pinggang Terhadap Tinggi Badan Dan Indeks Massa Tubuh Dengan Kadar Asam Urat Wanita Usia 45-55 Tahun. J Nutr Coll. 2017;6(4):357.

16. Malinti E, Malinti E. Tekanan Darah Dan Hubungannya Dengan Indeks Massa Tubuh Dan Aktifitas Fisik Pada Wanita Dewasa. J IIm Keperawatan (Scientific J Nursing). 2020;6(2):178-83.

17. Wowor T, Jaelani. Hubungan Indeks Massa Tubuh (IMT) dengan Tekanan Darah Pada Usia Dewasa di RW.08 Keluhan Mekarbakti Kecamatan Panongan. J Educ Nurs [Internet]. 2018;1(1):32-47. Available from: https://ejournal.akperrspadjakarta.ac.id

18. Arianti I, Husna CA. Hubungan Lingkar Pinggang Dengan Tekanan Darah Masyarakat Di Wilayah Kerja Puskesmas Mon Geudong Tahun 2015. AVERROUS J Kedokt dan Kesehat Malikussaleh. 2018;3(1):56.

19. Jufri AJ, Umboh A, Skripsi K, Kedokteran F, Sam U, Manado R. Di Pegunungan Dan Tinggal Di Tepi Pantai. 2015;3(April):452-6.

20. Nuraini B. Risk Factors of Hypertension. J Major. 2015;4(5):10-9.

21. Buford TW. Hypertension and aging. Ageing Res Rev [Internet]. 2016;26:96-111. Available from: http://dx.doi.org/10.1016/j.arr.2016.01.007

22. Fava C, Sjögren M, Montagnana M, Danese E, Almgren P, Engström G, et al. Prediction of blood pressure changes over time and incidence of hypertension by a genetic risk score in swedes. Hypertension. 2013;61(2):319-26.

23. Bantas K, Yoseph HK, Moelyono B. Ukuran Lingkar Pinggang Optimal untuk Identifikasi Sindrom Metabolik pada Populasi Perkotaan di Indonesia. Kesmas Natl Public Heal J. 2013;7(6):284.

24. Farkhondeh T, Llorens S, Pourbagher-Shahri AM, Ashrafizadeh M, Talebi M, Shakibaei M, et al. An Overview of the Role of Adipokines in Cardiometabolic Diseases. Molecules. 2020;25(21):1-16. 